\title{
Online Learning: Student's Perception off Lecturer's Competence and its Influence on Achievement Motivation
}

\author{
Jaka Wijaya Kusuma1,a", Hamidah ${ }^{1, b}$ \\ ${ }^{1}$ Department of Mathematics Education, Faculty of Teacher Training and Education, \\ Bina Bangsa University, Serang, Indonesia \\ a jakawijayak@gmail.com; b shiroimida@gmail.com \\ *Corresponding Author : jakawijayak@gmail.com | Phone Number: 085718831118
}

Received: 19 November 2020

Revised: 8 January 2021

Accepted: 16 February 2021

\begin{abstract}
In the midst of the current pandemic, online learning is the main choice in the world of education. However, there was a wide range of student responses to the learning process. Furthermore, it is known that the perception of students towards learning submitted by influential lecturers to generate interest in learning students in understanding the materials provided. Therefore, the purpose of this study is to obtain concrete information about: 1) how students perceive the competence of lecturers in applying online learning; 2) how to motivate students to excel during online learning; and 3) is there any influence of student perception on the competence of lecturers with the motivation of student achievement. This research uses a combination research design and its data collection method, namely survey by providing questionnaire questionnaire link with googleform. The subjects of the study were 274 students of the even semester of the academic year 2019/2020 at Bina Bangsa University who responded to the poll. The conclusion is that the perception of students is very diverse towards the competence of lecturers in applying online learning, as well as the motivation of student achievement. Although the percentage of incline is positive, not a few have responded negatively. Furthermore, it is known that there is a significant and moderate influence between the perception of students towards the competence of lecturers and the motivation of student achievement. In other words, if the student's perception of lecturer's competence increases, it will be accompanied by increased motivation for student achievement.
\end{abstract}

Keywords: Perception; Lecturer Competency; Achievement Motivation; Online Learning

\section{Introduction}

Lecturers are an important element in the education system in a college. According to (Ricoida et al., 2019) lecturers play an important role in creating quality graduates where it is the purpose of education. To create qualified graduates, a lecturer should have quality competencies as well. The competencies of lecturers according to the laws of Teachers and Lecturers and PP No. 19/2005 include personality, pedagogical, professional, and social competencies. Competency in question from various perspectives both in terms of material delivery, learning methods, student understanding, material mastery, interaction with students, communication, discipline and responsibility. Furthermore, in the midst of the current pandemic the majority of the learning process is required to be done online. According to (Zhafira et al., 2020) with the Covid-19 outbreak in early 2020, the government then issued an appeal to conduct learning activities from home in order to break the chain of virus spread and maintain the safety and security of students and educators. This means that a lecturer is required to be able to prepare a competent online learning process in all directions so as to create qualified graduates.

A lot of research has been done to explore the effectiveness of online learning implemented in the past semester. Some of them are According to (Saifuddin, 2017) which mentions that online learning can increase interactivity and learning efficiency because it gives students a higher potential to communicate more with lecturers, colleagues, and access more learning materials. Furthermore, the results of the study According to (Kusuma \& Hamidah, 2020) are known that during online learning, students are in different locations with different signal strengths, so few complain about the difficulty of signaling to be able to join in learning. In line with this, the results of the study According to (Riyanda et al., 2020) are known that students' activeness in participating in activities during online learning tends to decrease with time, limited understanding and ability of educators in using V-Class systems, unstable internet connections, and the unpreparedness of 
educators for updates in the learning system. Further research According to (Adnan \& Anwar, 2020) mentions that lack of proper interaction with instructors is another major concern associated with online learning.

A wide range of opinions on online learning, from positive statements to negative statements. This certainly needs to be analyzed because the quality of online learning has an impact on the motivation of students' learning during learning, further affecting the ability obtained by students. According to (Firmansyah \& Rizal, 2019) the motivation that arises from within the student affects the achievement of the expected ability. Furthermore, the results of the study According to (Mafrudhoh et al., 2019) are known that the higher the motivation of achievement then the higher the self-reliance of learning which in this case will affect his ability after learning. According to (Arifin et al., 2019) positive student perception of the learning submitted by lecturers is necessary to generate interest in learning students in understanding the courses given. So the purpose in this study is to know: 1) how students perceive the competence of lecturers in implementing online learning that is taking place during this pandemic; 2) how to motivate students to excel during online learning; and 3) is there any influence of student perception on the competence of lecturers with the motivation of student achievement.

\section{Materials and Methods}

This study uses a combination method design that collects and analyzes between quantitative and qualitative data in the same study. The design of the combination research aims to complement each other's description of the results of the research on the events studied and to strengthen the analysis of the research According to (Wijatiningsih \& Prasetyawan, 2017). The subjects in this study were active students of the even semester of the 2019/2020 academic year at Bina Bangsa University who responded to a poll given online. The method of data collection is the survey method that is data collection by providing questionnaire questionnaire link with googleform to the research subject. The following stages performed in this study are:

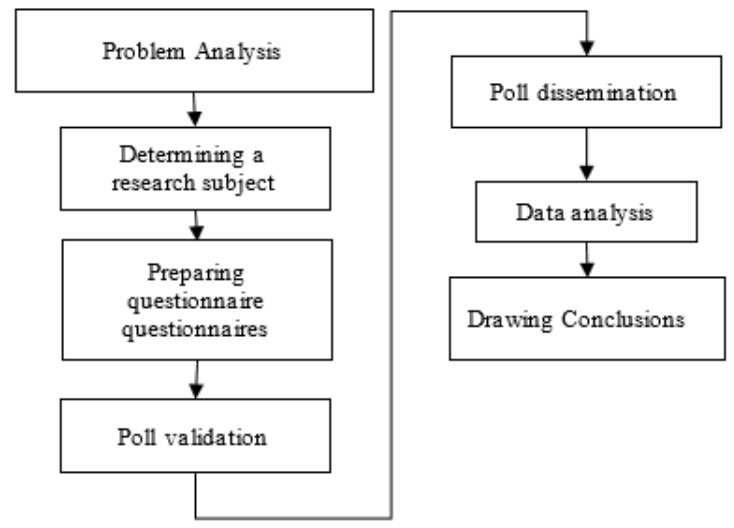

Figure 1. Stage of Research

a. The problem analysis is to analyze the phenomenon experienced by students during online learning. The results of the analysis are then formulated into a problem that will be analyzed more thoroughly as research.

b. Determining the subject of research is students of Bina Bangsa University who are active in the even semester of the 2019/2020 school year all majors that respond to polls distributed online.

c. Questionnaire questionnaires are created according to the indicators of each research variable. Motivational indicators of student achievement are having personal responsibility, setting the values to be achieved, trying to work creatively, trying to achieve goals, and doing their best activities. Each indicator is made 4 statements so that the total statement for the motivational poll is accomplished there are 20 closed statements. Indicators of student perception about lecturer competency during online learning are material delivery, learning methods, assessment, student understanding, material mastery, interaction, communication, discipline, and responsibility. Each indicator is made one closed statement and one open question, respectively.

$\mathrm{d}$. The questionnaire is made according to the problems in the research and validated by 2 expert lecturers.

e. The spread of polls is done online by spreading googleform links. The questionnaire is given to all students of Bina Bangsa University with a period of 2 weeks in July. From the results of the distribution of questionnaires to all students of Bina Bangsa University, which responded there were 274 students who were further the subject of research. 
f. The collected data is then analyzed. Quantitative data is analyzed with correlation tests to find out the influence, descriptive statistical tests to determine the percentage of each category. Qualitative data from open questions is analyzed by way of content analysis to gain insight into student perception to support quantitative data.

g. Withdrawal of conclusions is made after the data is finished being analyzed.

For quantitative data in the spread of scores are classified in the table to see the intelligence of each score by using the ideal mean (Mi) and ideal deviation standard (SDi) of the research subject. Categorization of measurement results using criteria developed by (Ningsih, 2019) can be seen in the following table:

Table 1. Interval Class Formula

\begin{tabular}{cc}
\hline Score Interval & Category \\
\hline$(M i+1,5 S D i)<X$ & Excellent \\
\hline$(M i+0,5 S D i)<X \leq(M i+1,5 S D i)$ & Good \\
\hline$(M i-0,5 S D i)<X \leq(M i+0,5 S D i)$ & Enough \\
\hline$(M i-1,5 S D i)<X \leq(M i-0,5 S D i)$ & Not Good Enough \\
\hline$X \leq(M i-1,5 S D i)$ & Not Good \\
\hline
\end{tabular}

\section{Results and Discussions}

The result of the distribution of questionnaires to all students of Bina Bangsa University was obtained by 274 students who responded. The data is then processed and analyzed. Students' achievement motivation is measured through a questionnaire of 20 statements using a likert scale with scores of 1 to 5 , so it is known the ideal parameter value is:

Ideal minimum score $=20 \times 1=20$

Ideal maximum score $=20 \times 5=100$

Ideal average value $(\mathrm{Mi})=(100+20) / 2=60$

Ideal deviation standard value $(\mathrm{SDi})=(100-20) / 6=13.3$

So it is known that each student's motivation score is in the following distribution table :

Table 2. Distribution of Motivational Frequency of Student Achievement During Learners

\begin{tabular}{cccc}
\hline Score Interval & Category & $\mathrm{F}$ & $\%$ \\
\hline $80<X$ & Very High & 42 & 15,33 \\
\hline $67<X \leq 80$ & High & 99 & 36,13 \\
\hline $53<X \leq 67$ & Less & 79 & 28,83 \\
\hline $40<X \leq 53$ & Low & 54 & 19,71 \\
\hline$X \leq 40$ & Very Low & 0 & 0 \\
\hline
\end{tabular}

Table 2 shows that more than $50 \%$ of students' achievement motivation during online learning is in the high and very high categories. It can be concluded that in general students have high achievement motivation during online learning. However, there are $48.54 \%$ of students whose motivation is underachieving and low. The percentage is not small, so it needs attention so that the motivation to perform students is even better during online learning.

Furthermore, students' perception of the competency of lecturers during online learning is measured through a questionnaire containing 9 statements using a likert scale with a score of 1 to 10 , so that it is known the ideal parameter value is:

Ideal minimum score $=9 \times 1=9$

Ideal maximum score $=9 \times 10=90$

Ideal average value $(\mathrm{Mi})=(90+9) / 2=49.5$

Ideal deviation standard value $(\mathrm{SDi})=(90-9) / 6=13.5$

So it is known that each student's perception score is found in the following distribution table:

Table 3. Distribution of The Frequency of Student Perceptions towards

\begin{tabular}{cccc}
\hline Score Interval & Category & $\mathrm{F}$ & $\%$ \\
\hline $70<X$ & Excellent & 37 & 13,5 \\
$56<X \leq 70$ & Good & 79 & 28,8 \\
$43<X \leq 56$ & Enough & 74 & 27 \\
$29<X \leq 43$ & Not Good Enough & 51 & 18,6 \\
$X \leq 29$ & Not Good & 33 & 12,1 \\
\hline
\end{tabular}


Table 3 shows the dissemination of data in each category from the results of the student's perception questionnaire of lecturers' competencies during online learning. This shows the diversity of responses given by students regarding the competence of lecturers. But in general the perception of students is relatively good, judging by the number is very good and good is greater than the number is less good and not good. Furthermore, the frequency distribution table will be viewed based on indicators of students' perception of lecturer competency during online learning.

Table 4. Frequency Distribution indicators of student perception of lecturer's competency during online learning

\begin{tabular}{ccccccc}
\hline $\begin{array}{c}\text { Student Perception } \\
\text { Indicator }\end{array}$ & \multicolumn{3}{c}{ Category (\%) } & \multicolumn{2}{c}{$\begin{array}{c}\text { Desrciption (Based on } \\
\text { Incline) }\end{array}$} \\
\cline { 2 - 7 } & Very Good & Good & Enough & $\begin{array}{c}\text { Not Good } \\
\text { Enough }\end{array}$ & Not Good & Negative \\
\hline Material Delivery & 9.49 & 8.76 & 28.83 & 13.14 & 39.78 & Negative \\
\hline Learning Methods & 14.60 & 10.58 & 32.85 & 12.77 & 29.20 & Positive \\
\hline Assesment & 28.10 & 14.23 & 30.29 & 6.93 & 20.44 & Enough \\
\hline $\begin{array}{c}\text { Understanding } \\
\text { Students }\end{array}$ & 18.61 & 15.33 & 32.12 & 8.03 & 25.91 & Enough \\
\hline Material Mastery & 39.78 & 16.06 & 27.01 & 4.38 & 12.77 & Positive \\
\hline Interaction & 23.72 & 18.25 & 28.47 & 9.12 & 20.44 & Positive \\
\hline Communication & 30.29 & 13.14 & 30.29 & 9.49 & 16.79 & Positive \\
\hline Disipline & 38.69 & 15.69 & 25.55 & 9.12 & 10.95 & Positive \\
\hline Responsibility & 46.72 & 12.77 & 24.09 & 5.84 & 10.58 & \\
\hline
\end{tabular}

*Negative if category: not good+not good >very good +good

Positive if category: very good $+>$ not good + not good

enough if category: very good + good=not good + not good

Based on table 4 it is known that the perception of students in the indicators of "material delivery" and "learning methods" is negative. This shows that these indicators contribute greatly to students' negative perceptions of lecturer competencies during online learning.

Furthermore, an overview of the exposure of some student answers is as follows:

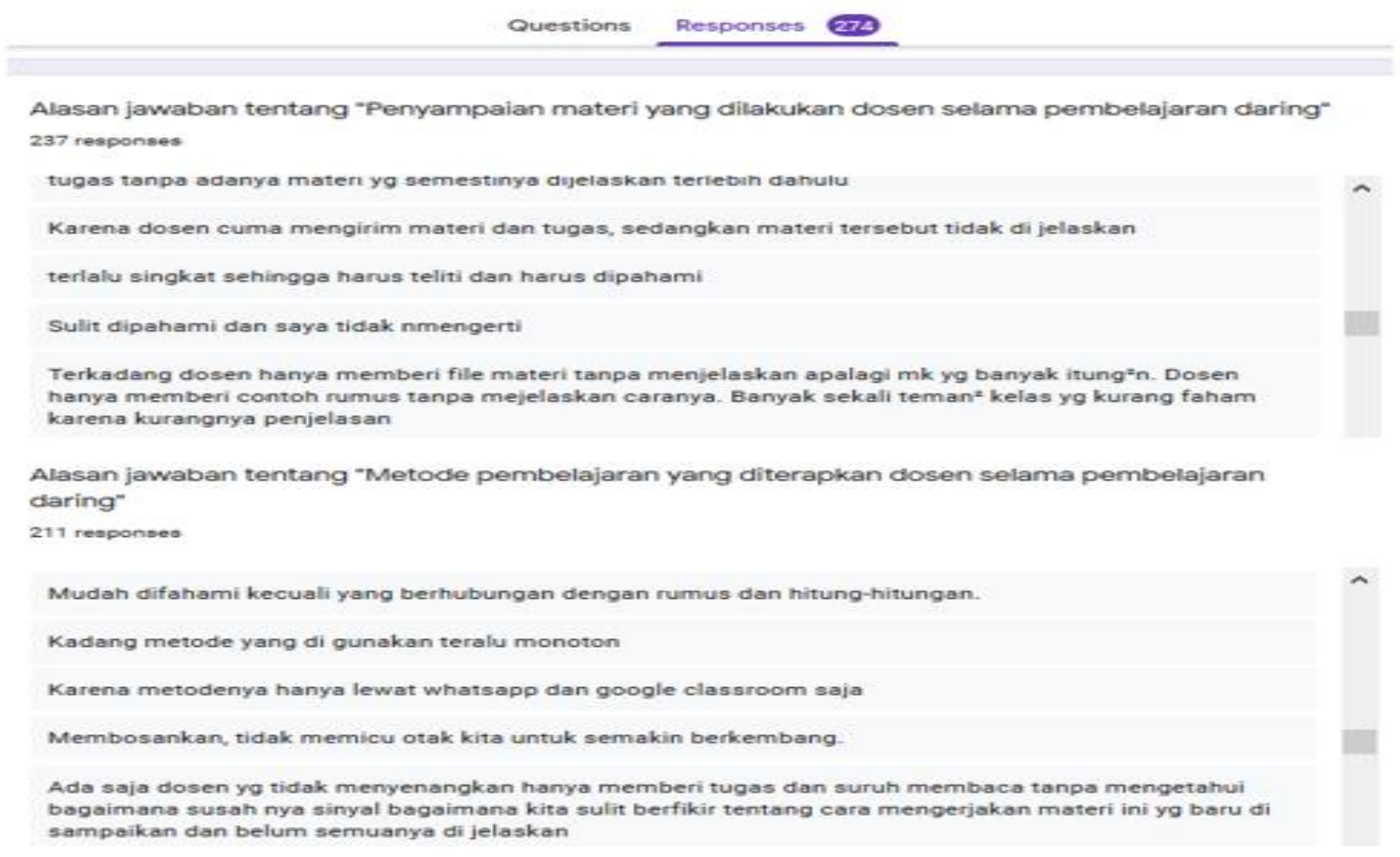

Figure 2. Exposure to Some Student Answers "Reasons for Answers About The Delivery of Materials and Learning Methods Conducted by Lecturers During Online Learning".

Based on figure 2 it is known that broadly the student's exposure to the reason for the answer to the indicator "material delivery" and "learning method" negative. Students give a lot of criticism regarding the way of delivery and learning methods that lecturers use during online learning.

The next result is a calculation to answer the third problem. To test the requirements of analysis already 
meet normality, linearity, and multicholinerity so that a hypothesis test can be performed. Hypothesis testing uses product moment correlation analysis techniques to determine the effect of student perception on the competence of lecturers with the motivation of student achievement.

Table 5. Product Moment Correlation Analysis Results Correlations

\begin{tabular}{|c|c|c|c|}
\hline \multicolumn{4}{|c|}{ Correlations } \\
\hline & & Student Perception & Achievement Motivation \\
\hline \multirow{3}{*}{ Student Perception } & Pearson Correlation & 1 & $.421^{* *}$ \\
\hline & Sig. (2-tailed) & & .004 \\
\hline & $\mathrm{N}$ & 274 & 274 \\
\hline \multirow{3}{*}{ Achievement Motivation } & Pearson Correlation & $.421^{* *}$ & 1 \\
\hline & Sig. (2-tailed) & .004 & \\
\hline & $\mathrm{N}$ & 274 & 274 \\
\hline
\end{tabular}

Pearson's Product Moment correlation analysis found a correlation coefficient of 0.421. ( $\mathrm{r}$ calculate) and the price of the determination coefficient $(\mathrm{r} 2)$ is 0.177 . This means that the motivation of student achievement is determined by $17.7 \%$ of the student's perception of the competency of the lecturer. The significance value of 0.004 is smaller than the 0.05 significance level, so it can be concluded that there is a significant correlation between the two variables. The correlation that occurs is positive, meaning that if the student's perception of the lecturer's competency increases, it will be accompanied by increased motivation of student achievement. The correlation that occurs is in the moderate category.

The results of data processing are known that students have a diverse perception of the competence of lecturers in general in applying online learning. There are $42.3 \%$ of students who respond well and very well to the competence of lecturers, but thus there are $30.7 \%$ of students who respond poorly and badly to the competence of lecturers. This shows that the online learning presented by lecturers in the lecture process did not go well. The results of open polls are known that not a few students are less motivated to engage in learning even to compete during the online learning process due to the unpleasant way of teaching lecturers and the lack of intercation between lecturers and students. This is in line with the opinion According to (Mustarin \& Wiharto, 2018) stating that what makes students interested in learning is how to teach educators and a calm, comfortable and interactive classroom atmosphere. Furthermore According to (Kent et al., 2019) states that in particular, interaction is the basis of online learning.

Based on further analysis, it is known that the perception of students in the indicators of "material delivery" and "learning method" tend to be negative is negative while the other indicators tend to be negative positive. This is known because there are more students who respond negatively than positive responses to the way materials and learning methods are used by lecturers during online learning. According to students as written in figure 2, not a few lecturers give assignments or materials in the form of modules, PPT or PDFs with less detailed explanations even some do not give explanations. Furthermore, students stated that learning is less effective due to lack of interaction and A during learning.

Related to the learning methods used by lecturers during online learning, according to students the learning method is less cool, less convenient, and sometimes constrained by signals. Often the method of delivery of lecturers is less clear so that there is a miscommunication in terms of material understanding and assignment. Students also stated that they prefer offline learning. According to (Jani, 2018) the learning strategy should be in accordance with the characteristics of the student and the conditions of learning. So lecturers should prepare the right learning model during online learning that suits the learning conditions and needs of students.

As it is known, these student complaints have a negative impact on their achievement motivations. This can be seen from table 2 which shows that $48.54 \%$ or 133 students showed low and underachieving motivation. The results of correlation analysis also showed that students' perception of the competence of lecturers contributed a moderate influence of $17.7 \%$ on the motivation of student achievement. Thus, improvements to the way materials are delivered and learning methods during online learning are necessary to improve students' perception of lecturer competency. Thus, a good perception of students towards the competence of lecturers will influence the increase in students' motivation to achieve. According to (Firmansyah \& Rizal, 2019) the motivation of excellence is a fundamental aspect that can affect activities during learning. Piaget's theory in According to (Deriyanto \& Qorib, 2018) states that a person tends to build his knowledge from the information they get from the media, friends, teachers and parents. This informs 
that online learning that utilizes internet media as a means of learning can build student knowledge. Furthermore, the role of lecturers is no less important in utilizing such media in interactive learning packaging. The results of data processing also show that not a few students also respond positively to online learning, one of the reasons is that it can be done anywhere and force students to search for information independently. This statement is certainly an interesting finding for lecturers to use in package a learning model that makes good use of internet media.

Based on the results of the student's answer can be explained that online learning is not yet effective in terms of conveying materials and the application of learning methods, but on the indicators of "discipline and responsibility" many students give a positive response. This is due to the advantages of online learning that can be done anywhere and makes it easy to find information and communicate. Then in the indicators of communication and mastery of lecturers to the material also showed a positive response. In other words, it was found that the problem that requires more attention is the lecturer's method of conveying material in online learning. Lecturers should be more maximizing in choosing and designing the right learning model in delivering materials during online learning. In online learning there are shortcomings that need to be addressed and there are also advantages that need to be utilized to the maximum. As said (Zhafira et al., 2020) the use of technology when balanced with proper guidance will be a learning tool that can develop high-level thinking skills.

\section{Conclusion}

Based on the above exposure, it is concluded that the perception of students is very diverse towards the competence of lecturers in applying online learning, as well as the motivation of student achievement. Although the percentage of trend is positive, not a few have responded negatively. Furthermore, it is known that there is a significant and moderate influence between the perception of students towards the competence of lecturers and the motivation of student achievement. In other words, if the student's perception of lecturer's competence increases, it will be accompanied by increased motivation for student achievement.

\section{References}

Adnan, M., \& Anwar, K. (2020). Online learning amid the COVID-19 pandemic: Students' perspectives. Journal of Pedagogical Sociology and Psychology, 2(1), 2-8. https://doi.org/10.33902/JPSP. 2020261309

Arifin, M., Muhajir, A., \& Muhajir, A. (2019). Analisis Persepsi Mahasiswa atas Kompetensi Pedagogik Dosen Pendidikan Agama Islam. Prosiding Seminar Nasional Pendidikan KALUNI, 2, 656-662. https://doi.org/10.30998/prokaluni.v2i0.149

Deriyanto, D., \& Qorib, F. (2018). Persepsi Mahasiswa Universitas Tribhuwana Tunggadewi Malang terhadap Penggunaan Aplikasi Tik Tok. JISIP: Jurnal Ilmu Sosial Dan Ilmu Politik, 7(2), 77-83. https://doi.org/10.33366/jisip.v7i2.1432

Firmansyah, A., \& Rizal. (2019). Potret Keterampilan Berpikir Kritis dan Motivasi Berprestasi Mahasiswa PGSD Universitas Tadulako. Jurnal Inspirasi Pendidikan, 9(2), 39-44. https://doi.org/10.21067/jip.v9i2.3323

Hamidah, H., \& Kusuma, J. (2020). Edukasi Guru Tentang Implementasi Gaya Belajar Siswa Dalam Pembelajaran Daring Di Era New Normal. MATAPPA: Jurnal Pengabdian Kepada Masyarakat, 3(2), 149-156. doi:http://dx.doi.org/10.31100/matappa.v3i2.648

Hamidah, S. P. M. P., Isnaini Mahuda, S. P. M. S., Jaka Wijaya Kusuma, S. P. M. P., Yollanda Octavitri, S. H. M. P., \& Pustaka, S. M. (2020). MATEMATIKA EKONOMI 1 \& 2: Untuk Analisa Ekonomi, Bisnis dan Ilmu Sosial. SCOPINDO MEDIA PUSTAKA. https:// books.google.co.id/books?id=y2vhDwAAQBAJ

JANI, J. (2020). Pengaruh Kompetensi Dosen dan Variasi Metode terhadap Prestasi Belajar Mahasiswa. Episentrum: Jurnal Ilmu Pengetahuan Sosial, 1(1).

Kent, C., Rechavi, A., \& Rafaeli, S. (2019). The relationship between offline social capital and online learning interactions. International Journal of Communication, 13, 1186-1211.

Kusuma, J. W., \& Hamidah, H. (2020). Perbandingan Hasil Belajar Matematika dengan Penggunaan Platform Whatsapp Group dan Webinar Zoom dalam Pembelajaran Jarak Jauh pada Masa Pandemik Covid 19. JIPMat, 5(1). https://doi.org/10.26877/jipmat.v5i1.5942

Mafrudhoh, Z., Sulistiani, I. R., \& Dewi, M. S. (2019). Hubungan Kemandirian Belajar Dengan Motivasi Berprestasi Mahasiswa PGMI Universitas Islam Malang. JPMI : Jurnal Pendidikan Madrasah Ibtidaiyah, 2(3).

Mustarin, A., \& Wiharto, M. (2018). Persepsi mahasiswa terhadap penggunaan program e-learning berbasis 
LMS pada Mata Kuliah Teknologi Budidaya Perikanan. Prosiding Seminar Nasional Lembaga Penelitian Universitas Negeri Makassar, 249-253.

Ningsih, S. (2019). Persepsi Mahasiswa Terhadap Mobile Learning Berbasis Android. Pedagogia, 17(1), 45. https://doi.org/10.17509/pdgia.v17i1.15858

Ricoida, D. I., Denny, D., \& Solihin, S. (2019). Sistem Informasi Penilaian Kinerja Dosen Dengan Metode Extreme Programming (Studi Kasus: STMIK MDP). JATISI (Jurnal Teknik Informatika Dan Sistem Informasi), 5(2), 216-225. https://doi.org/10.35957/jatisi.v5i2.147

Riyanda, A. R., Herlina, K., \& Wicaksono, B. A. (2020). Evaluasi Implementasi Sistem Pembelajaran Daring Fakultas Keguruan dan Ilmu Pendidikan Universitas Lampung. Jurnal IKRA-ITH Humaniora, 4(1), 6671.

Saifuddin, M. F. (2017). E-Learning Dalam Persepsi Mahasiswa. Varia Pendidikan, 29(2), 102-109. https:/ / doi.org 10.23917/varidika.v29i2.5637

Wijatiningsih, D., \& Prasetyawan, Y. Y. (2017). Penerapan Pengajaran Literasi Informasi Bagi Pustakawan Upt Perpustakaan Politeknik Negeri Semarang: Sebuah Penelitian Metode Campuran (Mixed Methods). Jurnal Ilmu Perpustakaan, 6(3), 191-200.

Zhafira, N. H., Ertika, Y., \& Chairiyaton. (2020). Persepsi Mahasiswa Terhadap Perkuliahan Daring Sebagai Sarana Pembelajaran Selama Masa Karantina Covid-19. Jurnal Bisnis Dan Kajian Strategi Manajemen, 4(1), 37-45. https:// doi.org/10.35308/jbkan.v4i1.1981 